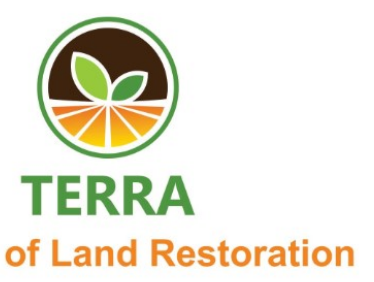

\title{
The Effect of Road Network on the Analysis Result of the Level of Degraded Land (The Case at Tanjung Aur Watershed, Bengkulu Province)
}

\author{
Bambang Sulistyo \\ Department of Soil Science, Faculty of Agriculture, University of Bengkulu, Kandang Limun, Bengkulu \\ email: bambangsulistyounib@gmail.com
}

\begin{abstract}
This study aims to investigate the effect of the road network on the results of the analysis of the level of degraded land at Tanjung Aur watershed, Bengkulu Province. The research method involves digital analysis of all the data affecting erosion and degraded land. The level of degraded land is defined as (Erosion + Slope + Percentage of Canopy Cover + Management), whereas the erosion itself is determined by the Universal Soil Loss Equation model and formulated as $A=R \times K \times L S \times C \times P$. All parameters are collected and then performed the analysis to produce as a map of the level of degraded land. Prior to the calculation of erosion and the level of degraded land, it is first made a map of land units which is the result of overlay analysis among land erodibility, slope and land use maps. In the first phase analysis, the calculation of erosion and the level of degraded land is done prior to the inclusion of road network, while in the second phase, calculation are done after the inclusion of road network. The results of the two analyzes are then compared to determine the effect of the inclusion of road network on the results of the analysis of the level of degraded land, either on the effect on the category changes in the level of degraded land and its coverage. The results showed that there were 690.42 hectares $(4.7 \%)$ of the study area $(14,684.86$ hectares) whose the level of degraded land was changed as a result of the inclusion of road network, from the level of "Potentially Degraded" to the "Slightly Degraded".
\end{abstract}

Keywords: erosion; the level of degraded land; the road network

\section{INTRODUCTION}

Degraded land is a global problem (Bohre and Chaubey, 2014). The amount of degraded land always increases over time, while the conservation rate can't overcome the rate of damage. The destruction of natural resources in Indonesia as all commodities from natural resources are exploited without regard to their carrying capacity (Kartodihardjo, 2008). The indications are the increasing number of floods, landslides, droughts, and the loss of various species from natural resources such as timber, rattan, medicinal plants, fish, various animals, and poverty (Hardjowigeno, 2007; Arsyad, 2010).

In 2002, the Ministry of Forestry released data that Indonesia has 96.3 million hectares of degraded forest land, 54.6 million hectares covering production forest areas, conservation forests and protected forests, while 41.7 million hectares are outside forest areas (Nawir et al., 2008). The data is of course currently has changed and tend to increase.

Efforts to conserve the degraded land conditions will be well implemented if objective information on the condition can be identified thoroughly (Tarigan,
2012, Gibbs and Salmon, 2015). The provision of such data and information is indispensable, especially in supporting the strategy that is efficient, so it is expected to obtain a reference to the allocation of resources proportionately. That is, to overcome the problem of degraded land it is needed a map of the Level Degraded Land (Abbreviated as LoDL, for further discussion) in such a way that can be known areas that must priority handled, what actions should be done, and how much funding needed.

However, the preparation of the map of the LoDL that describes the actual condition will take a long time, resources and funds if the survey is done directly through the terrestrial survey. To overcome this problem, a model can be made to map the LoDL without having to conduct a survey directly. The Department of Forestry (the then, the Ministry of Environment and Forestry) has developed a model of degraded land mapping and has been implemented in Indonesia, especially through the Watershed Management Agency (BP DAS) scattered throughout the province in Indonesia. Guidelines for conducting degraded land analysis were published in 1998 and updated in 2009 (Department of Forestry, 1998; Ministry of Forestry, 2009). 
The Level of Degraded Land is defined as : LoDL $=\mathrm{w}_{1}$ Slope $+\mathrm{w}_{2} \mathrm{TBE}+\mathrm{w}_{3}$ Percentage of Canopy Cover $+\mathrm{w}_{4}$ Management

where $\mathrm{w}_{1}, \mathrm{w}_{2}, \mathrm{w}_{3}$, and $\mathrm{w}_{4}$ are specified weights. TBE is the Level of Erosion Hazard that is generated by overlaying erosion results with the soil depth map. The amount of erosion is calculated using the USLE (Universal Soil Loss Equation) formula (Wischmeier and Smith, 1978):

$$
\mathrm{A}=\mathrm{R} \times \mathrm{K} \times \mathrm{LS} \times \mathrm{C} \times \mathrm{P}
$$

Where: $\quad \mathrm{A}=$ mean annual soil erosion rate in (ton/ hectares/year); $\mathrm{R}=$ rainfall erosivity factor ( $\mathrm{R}$ factor) in (MJ mm/ha/h/year); $\mathrm{K}=$ soil erodibility factor ( $\mathrm{K}$ factor) in (ton hectares $/ \mathrm{MJ} / \mathrm{mm}$ ); $\mathrm{LS}=$ slope length and steepness factor (LS factor) (dimensionless); $\mathrm{C}=$ cover and management factor ( $\mathrm{C}$ factor) (dimensionless); $\mathrm{P}=$ support practice factor ( $\mathrm{P}$ factor) (dimensionless)

The model is widely adopted by various Government Institutions, NGOs and universities (Prasetya and Gunawan, 2012). Nevertheless, Sulistyo (2011) has conducted a study using raster-based data supported by remote sensing data and GIS (Geographic Information System) which concludes that the model already built needs revision. Sulistyo (2008) conducted a study to determine the effect of land unit elimination on the amount of surface erosion that occurred in Air Nelas Watershed in Bengkulu Province.

Prior to the calculation of erosion and the LoDL, it is first made a map of land units which is the result of overlay analysis among land erodibility map, slope map and land cover map. In the determination of the land unit does not include the road network map, whereas, with the road network, the direction of flow of rain water (as one cause of erosion and the degraded land) will change. Likewise, the cutting of land units by the road network will cause a change in the LS factor that will ultimately affect the erosion and the LoDL. Oktaviano et al. (2013) has concluded that the road network has affected the erosion as much as $39.07 \%$ deviation as compared to the erosion when it was calculated without the inclusion of the road network.

The specific purpose of this research is to investigate the influence of the road network on the results of the analysis of the LoDL, especially at Tanjung Aur Watershed, Bengkulu.

\section{MATERIAL AND METHOD}

This research is continuation of the research dealing with the degraded land that has been initiated by Oktaviano et al., (2013). Therefore, the data, hardware, software, research area and methods were partly and almost similar to those research previously done.

\section{Study Area}

The study area is in Tanjung Aur Watershed which is administratively included in the border of Bengkulu City, Central Bengkulu and Seluma regencies, Bengkulu Province. Geographically located between East Longitude $102^{\circ} 23^{\prime} 19^{\prime \prime}$ to $102^{\circ} 366^{\prime} 50^{\prime \prime}$ and South Latitude $3^{\circ} 44^{\prime} 41^{\prime \prime}$ to $4^{\circ} 0 " 48^{\prime \prime}$. The area covers $40,852.83$ hectares.

\section{Data and programs used}

Required data include Topographic Map; Land/ Land Unit Map; Watershed Map; Satellite Imagery of Landat TM; and monthly rainfall data for 10 years. Software and tools include ILWIS Program version 3.3. to process raster-based data; and ArcView version 3.3 for vector-based data analysis and for map layout; binoculars, compass, soil sample ring, and GPS for field equipment; and other supporting equipment.

\section{Stages of research}

A simple flow diagram of how the surface erosion calculation with or without regard to road network factors is presented in Figure 1. Research stages include: 1) preparation, 2) digital classification, 3 ) data and map analysis, 4) digitization, 5) field work, 6) reinterpretation and analysis, and 7) the writing and making the map.

\section{Analysis of erosion and The LoDL}

All parameters related to the LoDL are collected and then analyzed for the final result presented as thematic maps. Prior to the erosion calculation, a landbased map of the land overlay analysis was established among land erodibility map, slope map and land use map.

In the first phase, the calculation of erosion and the LoDL are done without the inclusion of road network, while in the second stage is calculated by the inclusion of road network. The results of the two analyzes are then compared to determine the effect of the road network on the LoDL. 


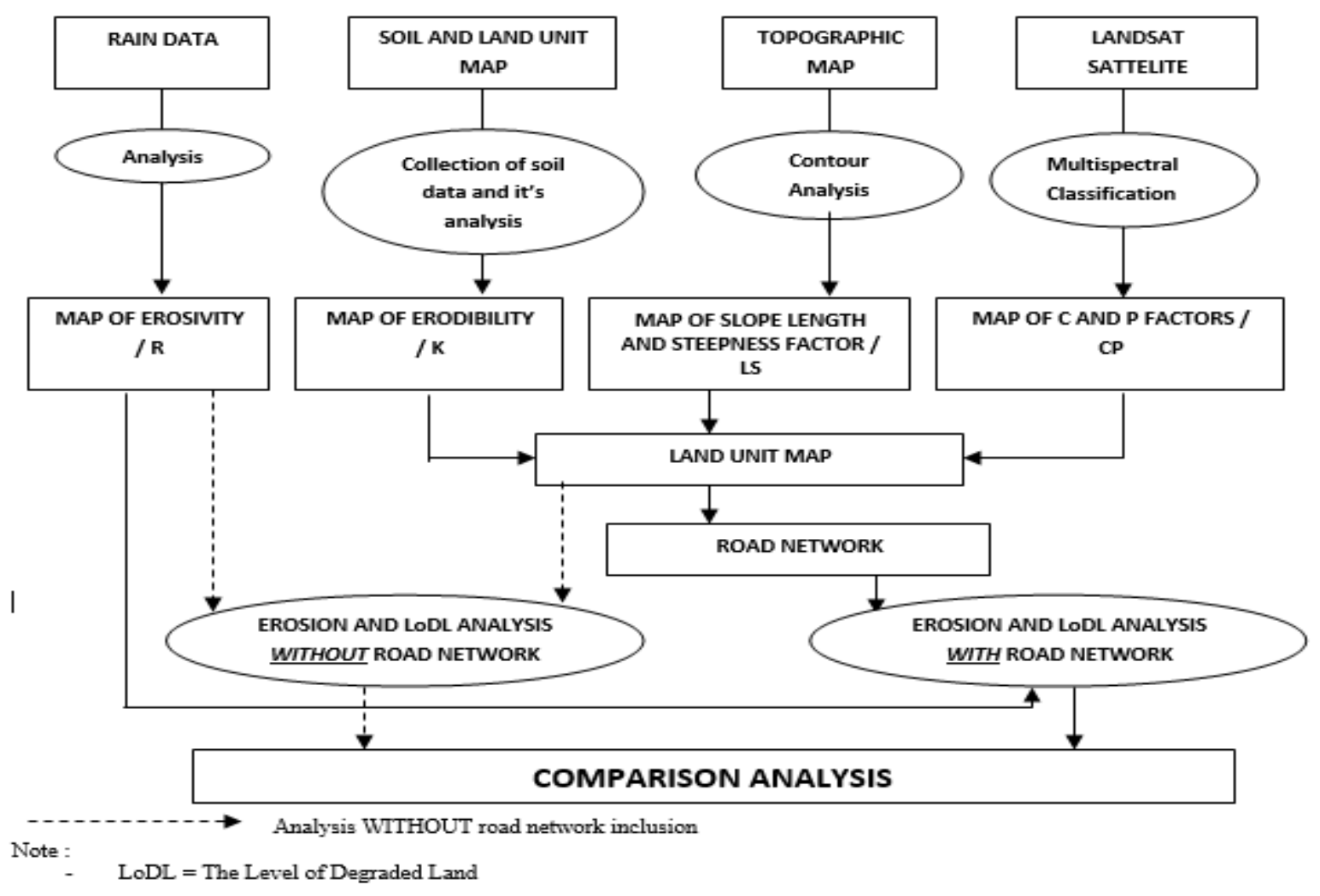

Figure 1. Flow diagram of the research

\section{RESULTS AND DISCUSSION}

\section{The Result of parameter analysis of the LoDL}

The result of Landsat TM interpretation shows that the Tanjung Aur Watershed is dominated by the existence of Secondary Forest (37.25\%), followed by Rubber Plantation (29.83\%), Annual Plants (19.18\%), Dense Forest (6, 66\%), Bare Land (3.99\%), Grass (1.92\%), Waterbody $(0.55 \%)$,
Mangrove $(0.32 \%)$, Rice Fields $(0.23 \%)$ and Coal Stockpile (0.07\%). From the landuse data, it can then be known $\mathrm{C}$ Factor, Percentage of Canopy and $\mathrm{P}$ Factor as presented in Table 1 .

From 10-year rainfall data observed at 4 observation stations located in and around Tanjung Aur watershed, the value of rain erosivities was 2.553 $\mathrm{cm}, 3.630 \mathrm{~cm}, 4.016 \mathrm{~cm}$ and $3.547 \mathrm{~cm}$ respectively (Table 2).

Table 1. Landuse in Tanjung Aur Watershed

\begin{tabular}{|c|c|c|c|c|c|c|}
\hline No. & Landuse & C Factor & $\% \mathrm{CC}$ & P Factor & Area (Hectares) & Area (\%) \\
\hline 1 & Waterbody & 0.001 & 0 & 0.04 & 224.23 & 0.55 \\
\hline 2 & Grass & 0.100 & 20 & 1.00 & 783.11 & 1.92 \\
\hline 3 & Mangrove & 0.001 & 20 & 1.00 & 130.69 & 0.32 \\
\hline 4 & Coal Stockpile & 0.950 & 0 & 0.40 & 28.26 & 0.07 \\
\hline 5 & Secondary Forest & 0.005 & 80 & 1.00 & $15,216.91$ & 37.25 \\
\hline 6 & Dense Forest & 0.002 & 100 & 1.00 & $2,722.64$ & 6.66 \\
\hline 7 & Rubber Plantation & 0.500 & 60 & 0.40 & $12,185.31$ & 29.83 \\
\hline 8 & Annual Plants & 0.400 & 40 & 0.90 & $7,836.87$ & 19.18 \\
\hline 9 & Bare Land & 0.950 & 0 & 1.00 & $1,629.42$ & 3.99 \\
\hline 10 & Rice Fields & 0.010 & 80 & 0.04 & 95.39 & 0.23 \\
\hline \multicolumn{5}{|c|}{ Total } & $40,852.83$ & 100.00 \\
\hline
\end{tabular}


Table 2. Rain Erosivity in Tanjung Aur Watershed

\begin{tabular}{lccc}
\hline \multicolumn{1}{c}{ Station } & Erosivity $(\mathrm{cm})$ & Area $($ Hectares $)$ & Area $(\%)$ \\
\hline Pulau Baai & 2,553 & $10,352.83$ & 25.34 \\
BPP Jayakarta & 3,630 & $3,670.11$ & 8.98 \\
Taba Penanjung & 4,016 & $6,358.59$ & 15.56 \\
Sukaraja Seluma & 3,547 & $20,471.31$ & 50.12 \\
\hline & & $40.852,92$ & 100.00 \\
\hline
\end{tabular}

The result of slope analysis showed that Tanjung Aur watershed was dominated by the slope $0-3 \%$ $(51.73 \%)$, followed by $8-15 \%(14.52 \%), 3-8 \%$ $(13.58 \%)$, the slope of $15-25 \%(9.42 \%)$, the slope $>$ $45 \%(5.61 \%)$, and the slope $25-45 \%$ (5.13\%) (Table 3). From Land Unit Map shows that Tanjung Aur Watershed is dominated by Hapludult $(34.44 \%)$, followed by Dystropept (26.24\%), Histosol (12.74\%), Hydraquent (8.65\%), Dystropept / Hapludult (4.97\%),
Dystropept / Eutropept (4.82\%), Tropopsamment (3.97\%), Eutropept $(1.05 \%)$ and Kandiudult $(0.86 \%)$ (Table 4). Table 4 shows that soil erodibility values vary from 0.001 (in Histosol area) to 0,520 (on Haplodult area).

The road network passing through the Tanjung Aur Watershed based on road status can be classified on national roads, provincial roads and city roads with the length of $211.9 \mathrm{~km}$

Table 3. Slope in Tanjung Aur Watershed

\begin{tabular}{ccrr}
\hline Kode & Slope & Area (Hectares) & Area (\%) \\
\hline 1 & $0-3 \%$ & $21,135.06$ & 51.73 \\
2 & $3-8 \%$ & $5,546.21$ & 13.58 \\
3 & $8-15 \%$ & $5,931.59$ & 14.52 \\
4 & $15-25 \%$ & $3,848.97$ & 9.42 \\
5 & $25-45 \%$ & $2,097.13$ & 5.13 \\
6 & $>45 \%$ & $2,293.88$ & 5.61 \\
\hline \multicolumn{4}{c}{ Total } \\
\hline
\end{tabular}

Source: Oktaviano et al., 2013

Table 4. Land Unit in Tanjung Aur Watershed

\begin{tabular}{rllrrr}
\hline No & $\begin{array}{c}\text { Land } \\
\text { Unit }\end{array}$ & Soil Type & Erodibility & Area (ha) & Area (\%) \\
\hline 1 & Af 121 & Tropaquent & 0.130 & 925.25 & 2.26 \\
2 & Af 122 & Eutropept & 0.140 & 428.54 & 1.05 \\
3 & Au 111 & Hydraquent & 0.170 & $3,533.22$ & 8.65 \\
4 & Bfq 11 & Tropopsammen & 0.450 & $1,620.06$ & 3.97 \\
5 & Bfq 12 & Haplodult & 0.520 & $2,933.62$ & 7.18 \\
6 & D 212 & Histosol & 0.001 & 932.77 & 2.28 \\
7 & D 213 & Histoso1 & 0.001 & $1,693.20$ & 4.14 \\
8 & D 222 & Histoso1 & 0.001 & $2,580.08$ & 6.32 \\
9 & Hab 111 & Dystropept & 0.270 & $3,393.39$ & 8.31 \\
10 & Hab 121 & Dystropept & 0.350 & 757.63 & 1.85 \\
11 & Hab 122 & Dystropept & 0.290 & $4,441.92$ & 10.87 \\
12 & Hq 11 & Kandiudult & 0.250 & 352.90 & 0.86 \\
13 & Ma 233 & Dystropept/Eutropept & 0.270 & $1,968.72$ & 4.82 \\
14 & Mab 222 & Hapludult & 0.260 & $5,888.07$ & 14.41 \\
15 & Mab 223 & Dystropept & 0.250 & $2,125.49$ & 5.20 \\
16 & Tf 21 & Hapludult & 0.270 & 468.04 & 1.15 \\
17 & Tf 32 & Hapludult & 0.230 & $4,049.66$ & 9.91 \\
18 & Tf62 & Dystropept/Hapludult & 0.310 & $2,031.29$ & 4.97 \\
19 & X1 & Hapludult & 0.190 & 729.00 & 1.78 \\
\hline \multicolumn{7}{r}{} & Total & & $40.852,83$ & 100,00 \\
\hline Source: Oktaviano & et al. 2013 & &
\end{tabular}




\section{Result Analysis of The LoDL}

The analysis results of erosion and the LoDL, both before and after inclusion of road network factors are presented in Table 5, Table 6 and Table 7. The results of the calculations presented are the results of the calculation on the land units crossed by road network. Meanwhile, the map of changes in the LoDL analysis is presented in Figure 1.

The results of the calculations as presented in Table 5 show that if it is calculated without regard to the road network, the amount of erosion occurring respectively 3,281.47 ton/ha/year, 2,766.69 ton/ha/year, 10,359.07 ton/ha/year, and 21,369.33 ton/ha/year when the slope is Very Flat, Flat, Weaving and Slopy. If calculated by observing the road network, especially on the left side, the amount of surface erosion occurring is $2,665.75 \mathrm{ton} / \mathrm{ha} / \mathrm{year}, 1,995.05 \mathrm{ton} / \mathrm{ha} /$ year, $7,814.94$ ton/ha/year and 14,345.12 ton/ha/year. Overall, the amount of erosion that occurs will decrease in the unit of land crossed by the road network. The reduction in the amount of surface erosion is a consequence of erosion calculating if calculated by considering the road network, as shown in Figure 2.

The process of erosion begins with the destruction of soil aggregates as a result of rain water blows that have more energy than soil resistance. The destruction of this soil will plug up the pores of the soil, so the infiltration capacity of the soil will decrease and cause water to flow at the soil surface and is called surface runoff. Surface runoff has the energy to erode and transport damaged soil particles. Furthermore, if the surface runoff is no longer able to transport the destructive materials, then these materials will be deposited. Erosion has three processes that work sequentially, beginning with the destruction of aggregates, transport and ending with precipitation (Rahim, 2006).

Table 5. The analysis of erosion, before and after inclusion of road network

\begin{tabular}{lcccc}
\hline \multicolumn{1}{c}{ Slope } & $\begin{array}{c}\text { Erosion Without } \\
\text { Road Network }\end{array}$ & \multicolumn{2}{c}{ Erosion With Road Network } & Area (ha) \\
& $3,281,47$ & $2,665,75$ & $2,599,11$ & $9,816,11$ \\
Very Flat $(0-8 \%)$ & $2,766,69$ & $1,995,05$ & $1,802,80$ & $2,493,65$ \\
Flat $(8-15 \%)$ & $10,359,07$ & $7,814,94$ & $6,381,58$ & $2,080,13$ \\
Weaving $(15-25 \%)$ & $21,369,33$ & $14,345,12$ & $14,936,56$ & 294,98 \\
Slopy $(15-25 \%)$ & & & & \\
\hline
\end{tabular}

Table 6. Area (ha) at every level of the degradation, before and after inclusion of road network

\begin{tabular}{lcc}
\hline Level & Without Road Network & With Road Network \\
\hline Highly Degraded & 6.91 & 6.91 \\
Degraded & 62.28 & 62.28 \\
Slightly Degraded & $6,623.52$ & $7,313.94$ \\
Potentially Degraded & $7,992.15$ & $7,301.73$ \\
\hline Total & $14,684.86$ & $14,684.86$ \\
\hline
\end{tabular}

Table 7. The ChangeArea of the LoDL, without and with Road Network

\begin{tabular}{lcc}
\hline \multicolumn{1}{c}{ Change in the LoDL } & Area (ha) & Area (\%) \\
\hline Change from "Potentially Degraded " to "Slightly Degraded" & 690.42 & 4.7 \\
No Change & $13,994.44$ & 95.3 \\
\hline Total & $14,684.86$ & 100.0 \\
\hline
\end{tabular}




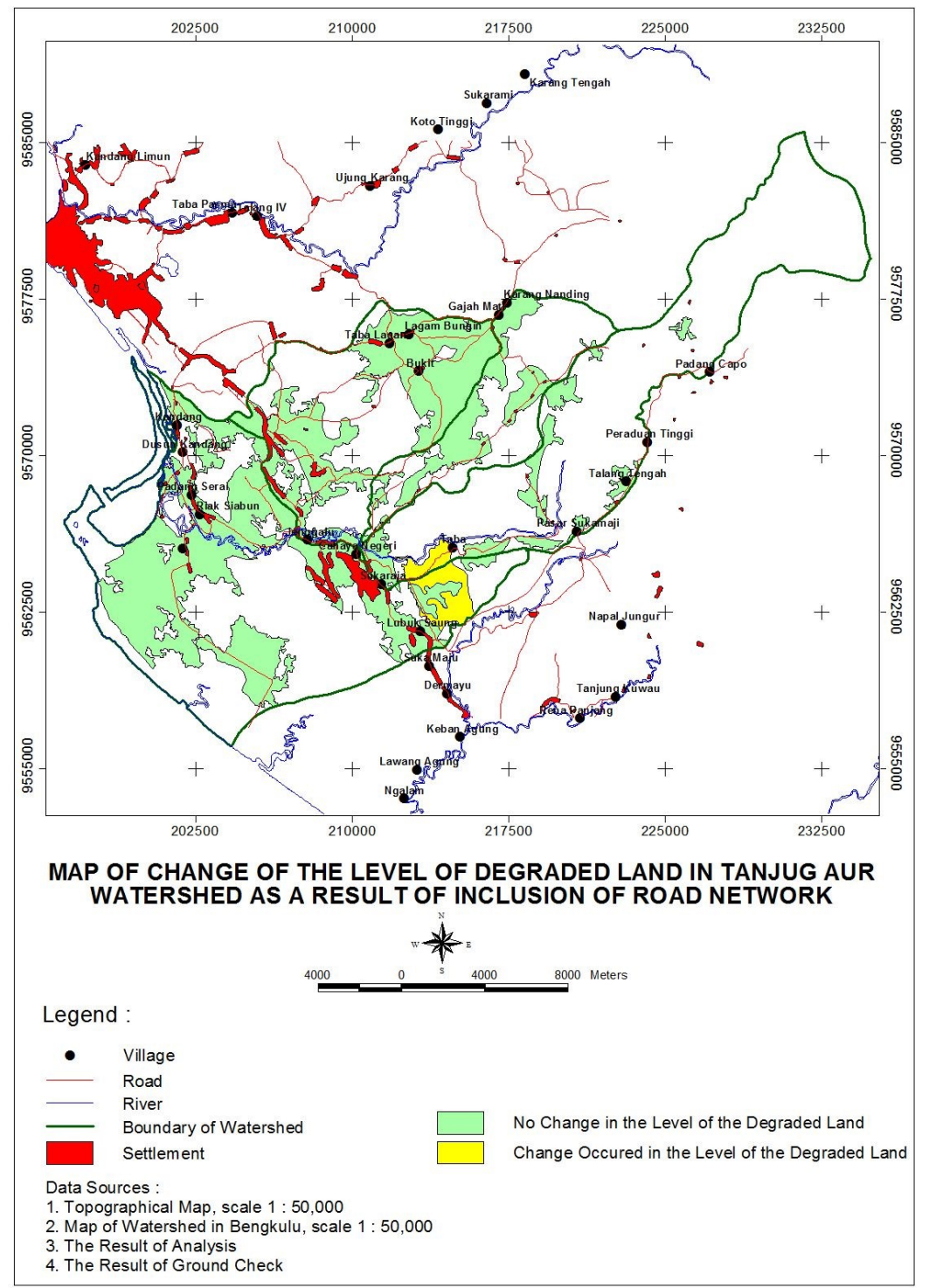

Figure 1. Map of change of the LoDL as a result of inclusion of road network
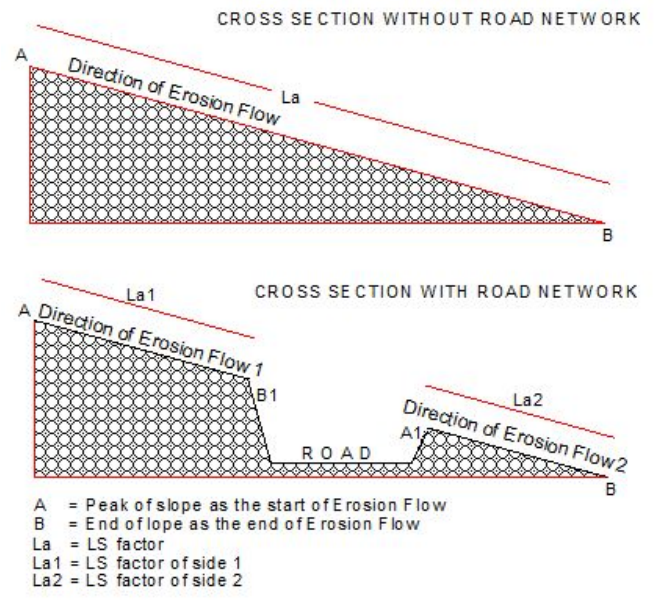

Figure 2. Cross section of the erosion flow without and with road network 
It should be pointed out that when a unit of land is cut by road network, $\boldsymbol{L} \boldsymbol{a}$ will turn into $\boldsymbol{L} \boldsymbol{a}_{\boldsymbol{1}}$ and $\boldsymbol{L} \boldsymbol{a}_{2}$ each and it is shorter than $\boldsymbol{L} \boldsymbol{a}$. If both sides are added to the erosion, it is likely that greater surface erosion will be obtained than the amount of erosion calculated on land units without crossing the road. However, according to what Rahim (2006) has implicitly implied, the erosion obtained from one side will decrease toward the road surface which will eventually follow the descending direction of the path.

In Figure 2 it is seen that when a unit of land has not crossed the road, $\boldsymbol{L} \boldsymbol{a}$ (the length of the slope or the length of the soil surface to be traversed by the erosion) is so large that it will produce a large surface erosion as well. This happens because the amount of surface erosion is directly proportional to $\boldsymbol{L a}$. However, when a land unit is crossed by a path, $\boldsymbol{L} \boldsymbol{a}$ will shrink in such a way that it will produce a shrinking surface erosion as presented in Table 5.

Table 6 shows the area (in hectares) of the results of the analysis of the LoDL acquired on the land units either with or without the inclusion of road network. The area obtained is $6.91 \mathrm{ha}, 62.28 \mathrm{ha}$, 6,623.52 ha, and 7,992.15 ha for the level of "Heavily Degraded", "Degraded", "Slightly Degraded" and "Potentially Degraded" for the units without the inclusion of road network. While for the units with the inclusion of road network are 6.91 ha, 62.28 ha, 7,313.94 ha, and 7,301.73 ha for the level of "Heavily Degraded", "Degraded", "Slightly Degraded" and "Potentially Degraded".

The presentation of the results in Table 6 is still not clear to determine the effect of the road network on the LoDL. The influence can only be known after conducting an overlay analysis between the two maps of the LoDL as presented in Table 7 and Figure 1.

Table 7 shows that there are only 690.42 ha $(4.7 \%)$ of the entire study area $(14,684.86 \mathrm{ha})$ where the LoDL changes as a result of the inclusion of road network, ie from the "Potentially Degraded" to the level of "Slightly Degraded". Nevertheless, the result raises further questions when it is associated with the result of erosion changes being significantly different. One of the reasons it can be argued is that it is impossible to compare the quantitative changes initially (in this case the change in the erosion) but then qualitatively (in this case the change of the LoDL). Another reason is the possibility of a weakness in the formulation of the LoDL as studied by Sulistyo (2011) is the use of analytical techniques by giving the scoring values. In addition, in equation (1) it has already mentioned in the preceding chapter there is a duplication of LoDL determinant parameters, ie Slope which is a duplication of $L S$ factor, Percentage of Canopy Cover is a duplication of $C$ Factor, and the actual Management is an action related to $\mathrm{C}$ and $\mathrm{P}$ Factors which are already mentioned in the USLE formula (Sulistyo et al., 2017).

\section{CONCLUSION}

There are only 690.42 ha (4.7\%) of the entire study area $(14,684.86 \mathrm{ha})$ where the LoDL changes as a result of the inclusion of road network, ie from the "Potentially Degraded" to the level of "Slightly Degraded".

\section{Acknowledgement}

The author would like to thank the Chairman of the Institute for Research and Community Service of the University of Bengkulu who has provided assistance in the administrative process for the purposes of this study.

\section{References}

Arsyad, S. (2010). Konservasi Tanah dan Air. Edisi kedua. IPB Press. (in Indonesian).

Bohre, P. and Chaubey, O.P. (2014). Restoration of degraded lands through plantation forests. Global Journal of Science Frontier Research. $14,18-27$.

Department of Forestry (Departemen Kehutanan), (1998). Pedoman Penyusunan Rencana Teknik Lapangan-Rehabilitasi Lahan dan Konservasi Tanah, Jakarta.(in Indonesian).

Gibbs, H.K. and Salmon, J.M. (2015). Mapping the world's degraded lands. Journal of Applied Geography. 57, 12-21.

Hardjowigeno, S. (2007). Ilmu Tanah. Akademika Pressindo, Jakarta. (in Indonesian).

Kartodihardjo, H. (2008). Pengelolaan Sumberdaya Alam dan Lingkungan Hidup, Seminar Lingkungan Hidup dan Sumberdaya Alam, Universitas Bengkulu, Bengkulu. (in Indonesian).

Ministry of Forestry (Kementerian Kehutanan), (2009). Peraturan Menteri Kehutanan RI Nomor : P. 32/Menhut-II/2009 tentang Tata Cara Penyusunan Rencana Teknik Rehabilitasi Hutan dan Lahan DAS, Jakarta. (in Indonesian).

Nawir, A.A., Murniati dan Rumboko, L. (2008), Rehabilitasi Hutan di Indonesia : Akan Kemanakah Arahnya Setelah Lebih Dari Tiga Dasawarsa?, CIFOR, Bogor. (in Indonesian).

Oktaviano, Sulistyo, B., dan Suhartoyo, H. (2013). Pengaruh Jaringan Jalan Pada Besarnya Erosi Permukaan (Studi Kasus Di Das Tanjung Aur, Provinsi Bengkulu), Jurnal Naturalis. 2(2), 213-221. (in Indonesian).

Prasetya dan Gunawan, T., (2012). Pemanfaatan citra penginderaan jauh dan sistem informasi 
geografis untuk pemetaan lahan kritis di daerah Kokap dan Pengasih Kabupaten Kulonprogo. Jurnal Bumi Indonesia. 1, 281-290. (in Indonesian).

Rahim, S.E, (2006), Pengendalian Erosi Tanah Dalam Rangka Pelestarian Lingkungan Hidup, Penerbit Bumi Aksara, Jakarta

Sulistyo, B., (2008), Pengaruh Generalisasi Unit Lahan pada Besamya Erosi, Jumal Ilmu Kehutanan, 2(1), Januari 2008, ISSN : 0126 - 4451. (in Indonesian).

Sulistyo, B., (2011). Pemodelan Spasial Lahan Kritis Berbasis Raster di DAS Merawu Kabupaten Banjarnegara Melalui Integrasi Citra Landsat $7 \mathrm{ETM}^{+}$dan SIG. Disertasi. Universitas Gadjah Mada, Yogyakarta. (in Indonesian).
Sulistyo, B., Gunawan, T., Hartono, Danoedoro, P., Martanto, R., (2017), Proposed Model On Levels of Degraded Land At Merawu Watershed, Banjarnegara Regency, Central Java Province, Indonesia, Biotropia. 24(3), 220-229.

Tarigan, S.D. (2012). Methods for delineating degraded land at Citarum Watershed, West Java, Indonesia. Journal of Tropical Soils. 17, 267274.

Wischmeier, W.H. and Smith, D.D. (1978). Predicting Rainfall Erosion Losses: A Guide to Conservation Planning. USDA Agriculture Handbook No. 37, USA. 